\title{
Indian Dalit Literature - A Reflection of Cultural Marginality
}

\author{
Soumya Nair Anoop Kumar
}

\begin{abstract}
The paper attempts to trace the impact of Indian Dalit Literature focusing on the question of Identity as well as Equality; cruelties by the subjugated group, exploitation of the untouchables, caste segregation, oppression by the dominant class, suppression of women turn out to be the subjects of this new genre of subaltern literature. The voiceless anger from the deep-rooted souls of the downtrodden weaker minds are clearly depicted in the writings which are articulated as Poems, short stories, novels or essays along with their biographical accounts in many case.
\end{abstract}

Index Terms-Identity, marginality, resistance, un-touchability.

\section{INTRODUCTION}

Dalit literature being a new dimension is the primary concept the literature of marginality. It can also be termed as the postcolonial nativist movement in creating castes, tribes and the voiceless suppressed by the voiced. Dalit Literature that remained speechless for centuries opened their hearts in the form of Poems, Ballads, Dramas, Short Narratives, Novels, Critical Essays, Biographies, Autobiographies and Historical Writings. The expressions were not fictitious as it was all their lives and created their own sphere. Poetry was highly realistic. The Dalit's outcry the injustice and cruelties encountered to them. Untouchability sustains throughout the era arriving at various forms or shapes and never disappears and changes its depth. Inequality is the root cause of marginality and literature the reflections of the outer reality of the inner self. Dalit Literature today is slowly elevating to the level of conventional literature. The resistance of this kind of literature is confronting from the dominant literary groups and the legitimacy is being granted in the snail pace as a new mode of literary/aesthetic imagination.

Post Structural and Post Modern theories paved way into cultural constitutions of the oppressed and marginalized communities. Frantz Fanon's Wretched of the Earth and Black Skin White Masks opened an enquiry into the culture based politics where the formation of colonial subjectivity and thereby the rise up of anti colonial resistance.

\section{OVERVIEW}

Dalit is a Sanskrit word which meant downtrodden, oppressive, exploitive or the peripheralistic lives. The term

Manuscript received September 7, 2016; revised December 9, 2016.

Soumya Nair Anoop Kumar is with the Department of English, \& Centre for Research St. Teresa's College Mahatma Gandhi University, Kerala, India (e-mail: soumyaanu_2005@yahoo.com). has become an identity to a segregated class of people like we call Negroes/ Blacks in Afro-America, the Aborigines in Australia and the Maoris in New Zealand. This genre of literature can be a reconstruction of the past. Dalit literature for a long time was ignored and not considered seriously in the mainstream literary genres. The fundamental human values like liberty, fraternity; equality, which can be the key factors of the Dalit literature, was a quest for identity in the society. Dalitness was reputable with different ideology corresponding with Dalit consciousness, Dalit aesthetics, Dalit arts, Dalit revolution and so on.

It persists as eternal in the attitudes of the voiced towards the voiceless. Never Dalits will be totally evacuated from the society. Dalits are like water. Water freeze and turn into ice and melt back to water again. The untouchable identities remain the same. India, being a multi lingua nation, the innate feelings of the Dalits are expressed through most of the languages like Marathi, Bengali, Gujarathi, Hindi, Kannada, Telugu, Tamil, Oriya and Malayalam. Dalit Literature can be termed as the protest literature with lot of frustration, anger, hope, and suppression. The main themes of Dalit writings are social disabilities, caste system, economic inequality, contemporary cruelties and cultural assertion that can be uniquely entitled as the struggle for identity. The writings replicate the resistance, issue of identity, experience of pain and moreover a communal distinctiveness.

"Conditions are ripe today for the 'outbreak' of dalit Studies. Everywhere it is aborigines/indigenous people who are subjected to the most inhuman kind of oppression and exploitation. The notion of oppressed, indigenous nationalities/minorities and a growing awareness of the racist/castiest core of dominant classes emerge from this panindigenous fact of oppression" [1].

(Towards a Prologue to Dalit Studies. Lines 1-3)

T. M. Yesudasan remarks in his essay Towards a Prologue to Dalit Studies that throughout the world the so-called 'other' is totally engaged in serious explorations of cultural schizophrenia. Dalits in the present day scenario are the nameless and faceless strata of the society. The poet Raghavan Atholi comments that Dalit is not the experience of one person but the humanity as a whole. Dalits were an abridged version of the formal slaves without the christening of the term. A new speculative language emerged to represent their identity. The Dalit sensibility arose in 1920s with the Dalit movements of Jyothiba Phule and Bhim Rao Ambedkar it spread to kerala only in the late 1970 s. The present day Kerala Dalit Literature emphasizes the relation with the social and political concerns. It shows it is not born out of any literary discussions but profound spiritual voice of 
Malayalam Dalit Writings was an influence by the teachings of Sree Narayana Guru, Ayyankali, as well as Sahodaran Ayyapan. Long before Ayyankali the founder of Sadhujana Paripalana Sangam (Organization of the Welfare of the Marginalised) realized the essence of social equality and justice. Ayyankali being an illiterate himself was the torchbearer for the education of the Dalits who were denied formal learning according to the age-old caste system.

Dalit writings in Malayalam did not receive its courtesy or due attention like the mainstream Malayalam literature where most of the works are translated into English. Kerala Dalits were conditioned in a dream that was transnational, anti imperialistic and anti-bourgeois. In Kerala the practice of untouchability existed even during the twentieth century era. Both the Brahmin community as well as the Dalit community lived in the same place and the caste system was divided on the basis of labour.

Malayalam Language an offshoot of Tamil language has its literary traditions in Sanskrit. Ramacharitham was the first Malayalam poem in the $14^{\text {th }}$ century. The poetry was not much heard to the world as they mainly subjected on the upper strata of the society. Later on in the $16^{\text {th }}$ century Thunchath Ezhuthachan's poetry was recognized and he became the father of Malayalam poetry even though he belonged to the OBC community of today. The interesting facts are his works were based on the Hindu mythology. In $18^{\text {th }}$ century the writings of Kunchan Nambiar who focused on Thullal kathakal portrayed the life of few backward communities like Parayan or Kaniyan. The stories, which were tuned to the rhythm of music and well sung by him, had a mock effect on the hypocracies of the dominant society.

Even though these were part of the innate culture of Dalits, the songs were sung by all but not the creator was recognized. Similarly the jobs done by the downtrodden made the upper community lead a royal life. Three traditions of Dalit Poetry are noticeable. All were basically oral traditions as there was no one to record their history. Koythupattu or the labour song, the songs of Panas or the Malayas (messenger songs) and finally the songs rooted in the ritualistic practices. The baskets made by the Paraya went to the temple but not the Parayas. The scriptures / deities were made by these men in the temple but the sculptor is not known or not recognised. In this context the words of Swami Vivekananda is commemorated and partially interpreted when we scratch a human being blood comes out but when you scratch an Indian caste comes out. The non-Dalit writers like Thakazhi, Kesev Dev, Ponkunnam Varkey, Lathimambika Antharjanam, Madavikkutty and M. T. Vasudevan Nair all endeavored to unveil the life of Dalits through their writings. Their writings neither attempted to search into the aesthetics or the epistemology relating to the life of Dalit groups such as Pulayas, Parayas, Arayas, Panas or others.

\section{A ShORT ANALYsis of DALIT POETRY}

About my Race...

I see no alphabet

oh there was no one in the ancient world

to write the story of my race!

When I think of it, regret begins

Within me

I'm not ashamed

Of the frailties of our castes

\author{
How is it \\ That God who gave shape to everything \\ today, allows everyone \\ to blame us in this manner \\ till earth and sky end?
}

(The Song by Poikayil Appachan)

[2] The Songs of Poikayil Appachan (Poikayil Appachan Paatukkal) was a maiden attempt by a Dalit writer, Poikayil Yohanan/ Poikyail Kumara Guru/ commonly known as Poikayil Appachan, who paved the way for the emergence of Dalit Poetry. His songs were composed to educate his own class of people and create awareness of the complex life each and every Dalit faces in this world. The anguish in the poetry depicts this state of no recognition of his survival in this small world. He outcries to the whole universe, there is no one in this world to record his life, to retell the story. The absence of the valid presence is a state, which the Dalits urged for, right from the beginning and that still remains an unanswered as well as un-attempted question. The poet asks the question to God why their men are only criticized or blamed and this remains as a fault forever. While the Dalit poets who themselves struggle for identity the poets of the mainstream literature are commenting or celebrating their poetic themes as love, nature, patriarchy, myths or traditions, etc.

The poem The Silent Beast [2] originally titled Mindaprani by M. R. Renukumar displays the number of jobs forcefully done by the Dalits. It was their life and they didn't have the authority to protest or no one to resist them in doing the same. All menial jobs that were done by the Dalits in a house where there was cattle- rearing is the subject of this poem translated by K. Sachidanandan. "Must clear the cattleshed, Of cowdung before, the milking begins." "Must collect the rice-water, from the backyard, of three neighbouring houses." Cattle-shed cleaning, collecting old rice water from the near by houses for the cattles, sharpening the sickle for cutting down the grass for the cow were the main activities for them which can be a realistic depiction of their own lives. As the poet composes these life events it is more or less an autobiographic aspect while comparing to the other mainstream poems.

Raghavan Atholi's Kandathi is another limerick that records the survival of the subordinate class. The poet wants to create a rhythm of his own people that was silent for ages. [2] He laments for them. For him it is just a poetry that he is not concerned with the dalitness contained in them. He wants his verse to be universal, to visualize the inner anxiety of his own people who are silenced for so long. His poetry is commented as 'not the worship of beauty. It is a historical commitment.' In this poem the women never speak, but the poet speaks for her. Kandathi is the name of the poet's mother. 
It denotes a woman who works in the rice field (kandam).

This battered woman,

My flesh and blood,

My mother.

Today

She waits for the light that went out to return,

For a handful of rice untainted with blood,

For a piece of land untainted with greed.

(last lines of the poem Kandathi) [2]

The poem also represents an element of solitude as well as a state of melancholy. The poet tries to express it through the innate feelings of his own mother. The 'she' in the poem is solely the symbol of a slavery of Dalit women. Social injustices, domestic violence and communal inequalities are the expressions presented here. The Dalit women are prone to cultural biases and communal atrocities since centuries. Women are twice outcaste, one from the society and second from the domestic male dominancy. Also we can interpret as one being a women and the other being a Dalit. Dalit literature being a powerful tool challenges the upper caste Hindu society. Dalit writings signal the unique dispensation of self-actualization and self-articulation.

Karumadi Nritham or the Black Dance by K.K.S. Das can be an image of protest poetry. The dance can be a war dance. The poet is a political activist in the forefront of many Dalit movements of 1960s as well as 1970s [2].

\section{We will pay them back for sure ! \\ We sacrificed roosters. \\ We fed the spirits \\ but now we become the prey}

(Black Dance lines 24-27)

These poem repeatedly uses again and again the outburst of anger towards the upper caste. Through this poem, the poet picturises the Cherumi tribe that is another downtrodden and oppressed group of people protesting silently to the dominant group. The tribes act as a group in a manner as if they are possessed. 'Take revenge' is highly synonymous voice of protest in most of the marginal literatures. The poem observes the suppressed voice of the self-experienced prejudice and atrocities.

Let tormented arms to be raised to avenge the wrong

Let uprooted tongues flare into flames

Let the oppressed rise to repay old debts

-Black Dance lines 57 to 60

All stand together; spill blood for one common reason that is the emancipation of the Dalits. The thirst for their liberation is strongly felt through the words of the poet. Dance is just an art form contradictorily signifies the disapproval of Dalits over the elite community.

\section{MARGINALITY}

"The margins nation displace the centre; the people of the periphery return rewrite $\mathrm{t}$ history and fiction of the metropolis". [3]

(Homi Bhabha. 1:6).

'Marginality' is a historically specific social construct marked by contingency mainly because it is discursive formation. The dialectics creates discursive openings for marginalized voices by questioning and displacing the location of power. [4] In India, the subaltern voices within the mainstream nationalism began to be heard much before the colonization. 1930s onwards, voices from repressed community in India, the untoucbable castes, Dalits, began to get increasingly audible Dalit creative and polemical writing which attempts in such writings to deconstruct the nation as conceived within the parameters of the Hindu nationalism of the nineteenth century provide rich angles of comparison with similar ideological forays made by the Aborgines of Australia through their creative writings. [5] Such literature funclions as a potent subaltenist mode and becomes a significant discursive site of resistance to elitist historiography, colonial and national Dalit Women Poets are struggling to justify with their own identities in their poems, mainstream poets are talking about love, patriarchy, equality, beauty, religion, myths and legends, social class, heritage, consciousness, position, children, food, economy, etc. Dalit poets concern is more liberal and autobiographical compared to the other modern poets. Their poetry is their past and present and future hence it is rebellious as well as reflective in nature. Savitribai Phule is guiding the women of her time to work. [6] She furthers adds that everything will be lost if we are not educated and it is education which gives us the wisdom and make us human. So, she says to her fellow sisters not to sit idle; get education so that they can end the misery of oppressed and forsaken.

[7] Poisoned Bread published in 1992 is one of the first anthologies in Indian Dalit Writing from Marathi Language. The voice of the Marathi speaking people were silenced for centuries until Jyoti Ram phule and Ambedkar stated their revolutionary works. Mahar was the main community in these regions who are the witnesses of the painful degradation during the colonial rule and specified them as untouchables. Alienation both social and psychic is an overaching thematic concern in this anthology. The readings reflect many of the theoretical and philosophical concerns of the Dalit Panther Movement. Arjun Dangle asserts this literature can bring about a revolution through materialistic approach through his collection of poetry, autobiographies, essays and this signifies the seminal moments of writing.

Dr. Jyoti Lanjewar's poem Caves gives the rebellious tone against the social inequalities of dominant society. She expressed that she had been silent all these days and was listening the voice of right and wrong. But, now she got the truth behind her communities existing status. She asks the simple question to the culture which was responsible for holding backward classes on such a filthy place. After examining such pitiful condition of her community she says this land was never mother to us.

"Which never gave us even the life of cats and dogs? I hold their unpardonable sins as witness And turn here and now, a rebel" [7]. 


\section{CONCLUSION}

Dalit literature that commenced as a protest literature has mellowed to incorporate the human race and the aesthetic justice. It is a new significant identity. Dalitness in the literature is no more a monotype. Also we understand this literature subscribe to secular values like individuality, liberty, equality and fraternity. [8] The most existing feature considered to be the recent trend in the field of Dalit literature is that the rising significance of woman poets, novelist and autobiography writers among the Dalits. Yet, the inadequate entity for the Dalit Literature is that till today it has not been recognized as a meta narrative national / universal literature. Thus Dalit literature can be observed as a literature of Marginality. Inspired by the Ambedkarite philosophy the literature makes it its guiding force. Morality and reliegion, therefore are not mere matters of likes and dislikes. [9] Sharan Limbale a prominent Dalit writer sets a trend for formation of Dalit aesthetics: author's experience be authentic; those experiences be generalized; those experiences should not be just region specific; text should instill inspiration for egalitarian social system. Finally the literature manifests the expression of prime values of independence, justice, equality, and fraternity humanizing its own literary space. The reading makes us agitated and leads to a social transformation and commonality towards the establishment of a non-repressive society.

\section{ACKNOWLEDGMENT}

This Research paper was supported by Dr. Latha Nair R.
Associate Professor, St. Teresa's College (autonomous). I would like to acknowledge my sincerest gratitude to my professor and guide.

\section{REFERENCES}

[1] K. Satyanarayana and S. Tharu, The Exercise of Freedom, India, Navayana Publishing House, 2013.

[2] M. Dasan, V. P. rathibha, P. Pampirikunu, and C. S. Chandrika, The Oxford Anthology of Malayalam Dalit Literature. New Delhi, Oxford University Press, 2012.

[3] H. Bhabha, Location of Culture, London: Routledge, 1994.

[4] G. Debjani, Caste and Dalit Life Worlds: Postcolonial Perspectives, New Delhi: Orient Longman Private Ltd, 2008.

[5] P. Kumar, Literature of Marginality, Comparative Perspectives in African, American, Australian and Indian Dalit Literature, New Delhi: Kalpaz Publications, 2014.

[6] G. Omvedt, Dalit and Democratic Revolution: Dr. Ambedkar and the Dalit Movement in India, Delhi: Sage Publications, 1994.

[7] A. Dangle, The Poisoned Bread, Chennai: Orient Black Swan, 2009.

[8] N. M. Aston, Literature of Marginality, Dalit Literature and AfricanAmerican Literature, New Delhi: Prestige Books, 2001.

[9] A. B. Rao, Annihilation of Caste, Essential Writings of B. R. Ambedkar, 2002.

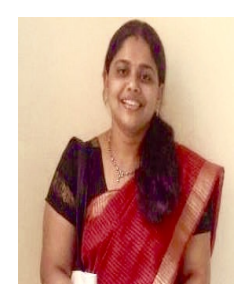

Soumya Nair Anoop Kumar is from India. She was born on May 7, 1983 in the city of Trivandrum, Kerala, India. She is a research scholar at Mahatma Gandhi University, Kottayam, India. She is having an ongoing thesis in English language \& literature focusing on the Dalit Literature of Kerala. She has completed her masters in English literature from Mahatma Gandhi University, in 2006. She was a Lecturer at the Department of English and Centre for Research, St. Teresa's college (autonomous). She has many articles with research content published to the international periodicals. 